\title{
Branching, Holding Companies, and Banking Concentration in the Eighth District
}

\author{
GERALD P. DWYER, JR., and WILLIAM C. NIBLACK
}

B ANK expansion through branching and bank holding company acquisitions has been the subject of nationwide discussion in recent years. Pressure has come from larger banks for fewer restrictions on branching and bank holding companies. The smaller banks have generally resisted such pressure and at the same time have pressed for greater restrictions on bank holding companies. Both groups have been active in the Eighth Federal Reserve District, as indicated by a number of recent changes in state laws.

The often heated debates about branching and multiple bank holding companies are concerned with the effect of these multi-office organizations on banking structure - the number and size distribution of banking organizations in an area. Of particular interest is the effect on concentration - the extent to which bank deposits are held in a few relatively large banking organizations in a market or a state.

The debate, however, is fundamentally about the effects of increased concentration. Those who favor branching or bank holding company expansion typically argue that any increase in concentration results from greater efficiency of these multi-office organizations and leads to improvement in services. One proponent of multi-office banking noted that in one state with state-wide branch banking:

. . there was no evidence of damage when a tiny, small-town bank, unable to pay the costs of automating and updating its facilities, unable to provide new customer services, unable to increase its lending limits and obtain funds at competitive rates, unable to attract and train top-notch bankers, agrees

- or asks for - a merger with a large institution. ${ }^{\text {t }}$

On the other hand, opponents of multi-office banking argue that it results in a concentration of economic and political power, to the detriment of the public.

1Address of Walter I, Charlton to the Mlinois Manufacturers Association, reprinted in American Banker (April 29, 1974).
As one opponent of multi-office banking put it:

Today we are once again threatened by superconcentrations of economic and political power. . . Such institutions, among them the multi-office giants of banking, have grown away from the people, are no longer responsive to the individual. It's "the public be damned," all over again, ${ }^{2}$

This article examines banking structure in Eighth District states, emphasizing concentration in states and Standard Metropolitan Statistical Areas (SMSAs). The effects of regulation-especially regulation of branching and holding company activity - on banking concentration are considered. Then, the effects of concentration on bank performance are analyzed.

\section{REGULATION AND BANKNG STRUCTURE N EIGHTH DISTRICT STATES}

Bank structure can be directly affected by regulation of entry, mergers, branching, and acquisitions of banks by multiple bank holding companies. Since state restrictions on entry and merger do not differ significantly in the Eighth District, one would expect to see little difference in bank structure among the states due to entry or merger laws. On the other hand, Eighth District state laws concerning branching and multiple bank holding companies differ considerably and may therefore contribute to differences in banking structure among the states. ${ }^{3}$ Less restrictive regu lation of branching and holding companies can affect structure by resulting in more branches or subsidiary banks and fewer independent banks. On the other

${ }^{2}$ Fred T. Brooks, "Irdependent Banking: A Hometown Philosophy," The Independent Banker (November 1973), p. 6 .

aThe Appendix to this article provides some details of the regulations on entry, merger, branching, and multiple bank holding companies in each of the Eighth District states. 
hand, it is also possible that branch banks or holding companies can increase the number of banking organizations operating in an area by establishing de novo branches or banks in an area in which they did not previously operate.

\section{Branching Regulation and Structure}

Illinois and Missouri are unit banking states, as was Arkansas until 1972. Arkansas now allows limited branch banking, as do the remaining states in the Eighth District. ${ }^{4}$ There is no state-wide branching in the District.

Effech of Branching on Enty and Merger - Opponents of branching argue that branching will result in a reduction in the number of independent banking organizations. This is likely to occur partly because branches will be opened where new banks might be established if branching were prohibited, and partly as a result of bank mergers. Such mergers are less likely to occur in unit banking states because the office of one bank would have to be closed or services offered at one office restricted.

In recent years the limited branch banking states in the Eighth District have had fewer new banks established and more mergers than the unit banking states. As indicated in Table $\mathrm{I}$, the ratio of the number of mergers to the number of new banks from 1968 to 1973 ranges from zero to 0.09 for the unit banking states and from 0.05 to 1.71 for limited branch banking states. The number of banks increased in the three unit banking states and in one limited branch banking state, Tennessee, and decreased in the three other limited branch banking states.

בVect of Branching on SMSA Concentration - This decreased entry and greater frequency of mergers has resulted in a greater concentration of deposits in branch banking states than in unit banking states. High concentration is especially likely for areas

4Ir tunit banking states a bank may not have full-service branches, although one or more limited-service facilities may be perritted within a limited distance from a bank's home office. In limited branch banking states, a bank may have more than one full-service office but may not operate fullservice offices at locations throughout the state. Arkansas is regarded as a mit banking state in the analysis that follows, since it was classified as such for four of the five years under consideration. smaller than states, if branching is limited to such areas. As the accompanying chart shows, the concentration of bank deposits in Eighth District SMSAs is greater in limited branch banking states than in unit banking states. The SMSAs included in the chart are the four largest SMSAs with population greater than 100,000 in each Eighth District state, except for Chicago which is excluded as atypical. The concentration measure used is the "four-bank concentration ratio" the percentage of total bank deposits in an area held by the four largest banking organizations. Since SMSAs can be taken as approximations of market areas for many banking services, the concentration ratios can be interpreted as market concentration ratios. $^{\mathbf{5}}$

The amount of business in a market also influences concentration; as the amount of business expands, the concentration of deposits generally declines. This can be seen most easily in a highly simplified example. Suppose there is a size of bank that is associated with minimum average cost and that entry is not regulated. Because of competition among existing firms

\footnotetext{
Banking markets are likely to be confined geographically because of the costs of visits to a bank. Only banks in a limited area are likely to be relevant alternatives for many customers. Various factors considered in defiuing SMSAs, such as commuting patterns, suggest that they are integrated economically. SMSAs as defined in 1970 are used with one change: parts of SMSAs that are not in the same state as the central city in the SMSA are excluded. For example, only the deposits in banks located in the Missouri portion of the $S$ t Louis SMSA are included in calculating the concentration ratio for St. Lotis. One reason for dong this is that banks across a state line are likely to be less relevant alternatives for bank custoners. For example, it may be more difficult to get a loan across a state line becanse costs associated with filing mortgages and repossession in another state would be greater.
} 


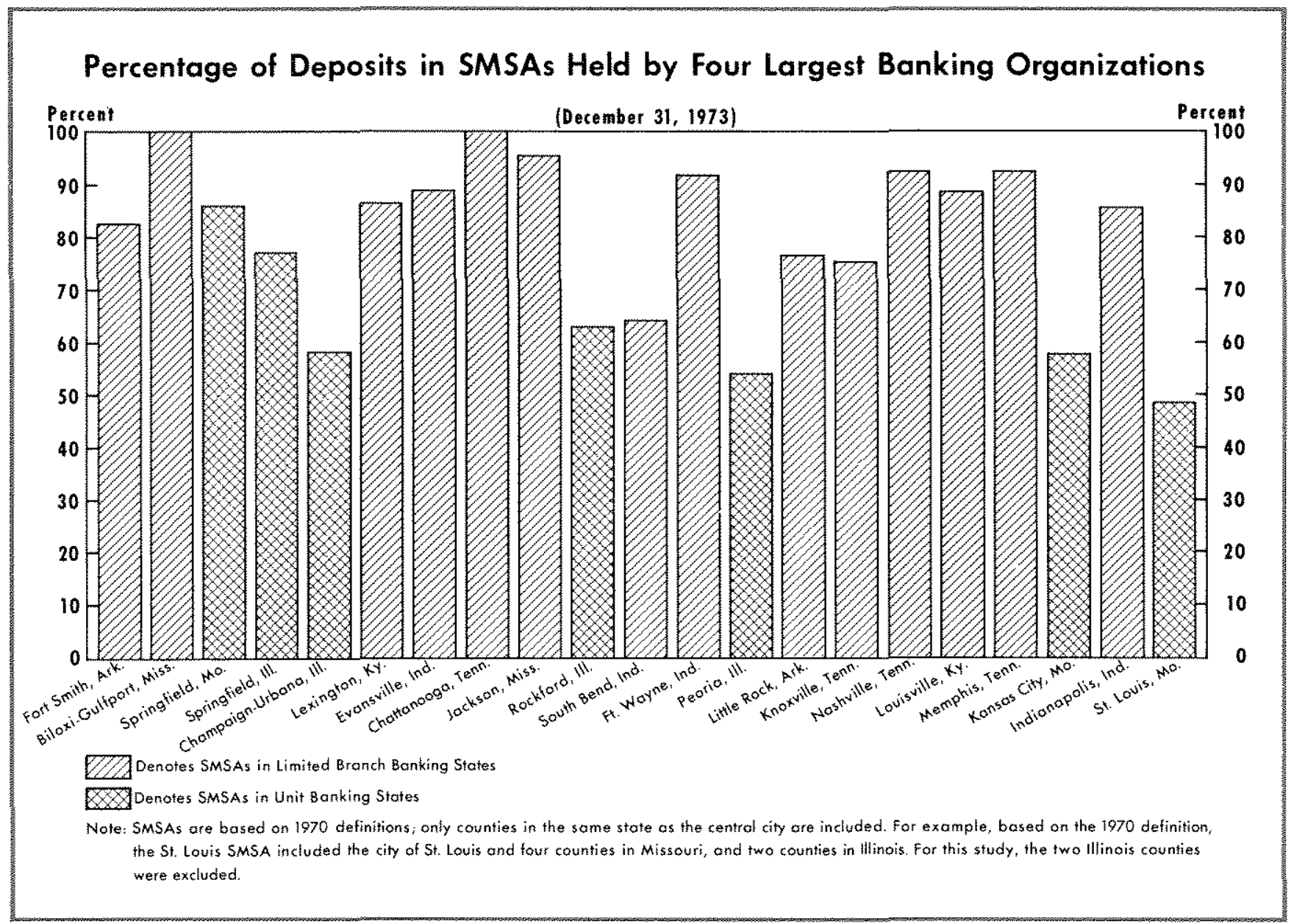

and entry of new firms, the average size of firms tends to be that which is associated with minimum average cost. Therefore, as a market expands new firms enter and concentration falls. The SMSAs in the accompanying chart are arranged on the basis of population a rough measure of market size - with the smallest on the left and the largest on the right. The fourbank concentration ratio tends to be lower in larger SMSAs than in smaller ones. For areas of approximately the same size, concentration is higher in the limited branch banking states than in the unit banking states.

\section{Multwple Bank Holding Companu Regulaton and Structure}

Most states in the Eighth District prohibit the formation of new multiple bank holding companies or the accuisition of additional banks by any existing holding companies. At present, only Missouri and Tennessee allow formation of multiple bank holding companies or further acquisitions by them. Recent legislation in Tennessee prohibits acquisitions by mul- tiple bank holding companies under certain circumstances. Legislation designed to restrict the size of multiple bank holding companies has also been enacted in Missouri. Both laws reflect concern over increased state concentration of bank deposits.

Recent Achivily - . In the last five years, the number of multiple bank holding companies has increased substantially in Missouri and Tennessee. In Missouri, there were 3 such companies at the end of 1968 and 24 at the end of 1973 ; in Tennessee, there were 3 at the end of 1968 and 9 at the end of 1973 . The number of banks in Missouri controlled by these holding companies at year-end 1973 was 144,12 times the number of banks controlled at the end of 1968 . Holding companies in Tennessee now control 48 banks, more than 5 times the number of banks controlled at the end of 1968. Acquisitions of existing banks account for the majority of the increase in subsidiary banks, but 7 banks in Missouri and 1 bank in Tennessee were chartered as de novo subsidiaries.

The shares of bank deposits in Missouri and Tennessee controlled by multiple bank holding companies 
have increased dramatically in the last five years. These companies controlled 9.4 percent of total Missouri bank deposits in 1968 and 55 percent in 1973. In Tennessee, they controlled 3.5 percent of total bank deposits in 1968 and 49 percent in 1973.

However, examining the effect of multiple bank holding companies on the share of state deposits in this way overstates the increase in the share of state deposits controlled by large organizations. The de posits in Missouri and Tennessee that are controlled by holding companies consist largely of deposits in the companies' lead banks. At year-end, deposits in lead banks were 37.1 percent of Missouri bank deposits and 39 percent of Tennessee bank deposits. These percentages accounted for 67.3 and 79.6 percent of the total deposits controlled by multiple bank holding companies in Missouri and Temessee, respectively. Thus, while the proportion of state deposits controlled by holding companies has increased dramatically, that increase primarily represents formation of holding companies by larger banks, rather than an increase in the concentration of deposits in large banking organizations.

Siate Comconation-A preferable way of looking at the effect of holding company acquisitions on concentration is to consider the effect on state concentration ratios, the share of deposits in a state held by a specified number of the largest banking organizations. This differs from looking at the share of deposits controlled by all multiple bank holding companies, since the smaller holding companies are not considered and the number of organizations is held constant.

If it is assumed that deposits of subsidiary banks grew at the same rate after acquisition as they would have without acquisition, then the increase in concentration is simply the difference between the actual concentration ratio and a calculated ratio which assumes no banks were acquired after 1968. Thus, it is estimated that multiple bank holding companies increased the four-bank concentration ratio by 9.4 percentage points in Missouri and 4.4 percentage points in Tennessee (see Table II). The comparable figures for the ten-bank concentration ratios are 12.8 percentage points for Missouri and 10 percentage points for Tennessee.

SMSA Concentration - The same procedure can be used to estimate the effect of multiple bank holding companies on the fourbank concentration ratios in SMSAs. No Tennessee holding company owned more than one bank in any of the four largest SMSAs by

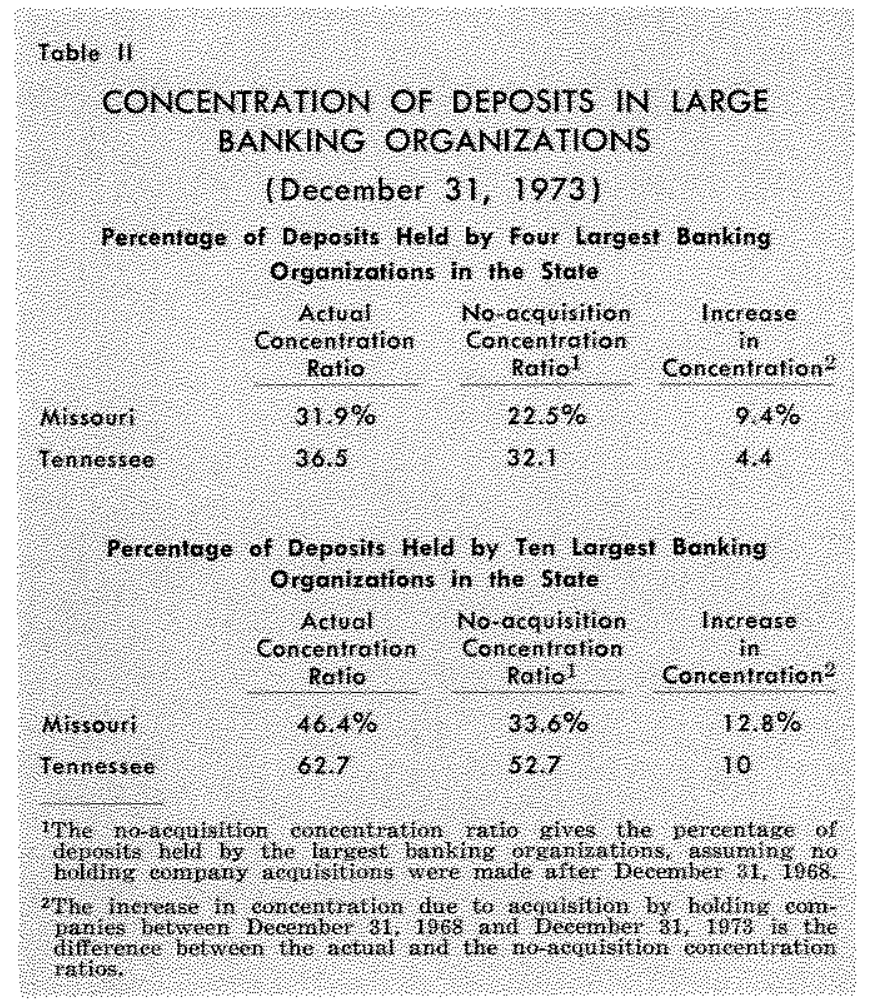

the end of 1973. If it is true that affiliation with a holding company neither increases nor decreases a bank's growth, then in 'Tennessee multiple bank holding companies have not affected SMSA concentration. On the other hand, holding companies have acquired two or more banks each in some Missouri SMSAs. In St. Louis, the concentration in the four largest banking organizations is 3.7 percentage points higher than the 44.7 percent without such acquisitions; in Kansas City, concentration is 5.3 percentage points higher than the 52.4 percent; and in Springfield, it is 4 percentage points higher than the 82 percent without such acquisitions. Undoubtedly, a contributing cause to this difference between Missouri and Tennessee is the prohibition of branch banking in Missouri and permission of county-wide branching in Tennessee.

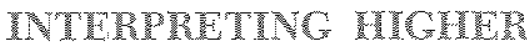

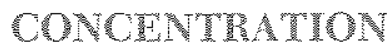

The foregoing discussion has shown that less restriction of branching and multiple bank holding companies is associated with higher concentration, but has given no basis for evaluating the significance of higher concentration. This is at the heart of the controversies about branch banking and multiple bank holding companies. An increase in a concentration ratio merely says that the percentage of deposits held by the largest banks has increased. It is the expected 
effects of this increase on the performance of the banking organizations that are of interest, not the increase itself.

Increases in concentration of banking resources in states have a completely different interpretation than increases in SMSAs. Concentration in a state is an aggregate concentration measure; concentration in an SMSA is a measure of market concentration. The essential aspects of an aggregate concentration measwre are that it is measured for a political entity, that it includes several markets, and that it emphasizes the relative sizes attained by some firms operating in several markets. Market concentration is measured, to the extent possible, for a geographic market - "the area within which the price of a commodity tends to uniformity, allowance being made for tramsportation costs." "

\section{Srate Concentration}

The effects some observers have attributed to an increase in banking concentration at the state level are on the prices charged and influence over the state govermment's legislative process. ${ }^{7}$ It is argued that the effect on market prices occurs through the ability of large organizations operating in several markets to agree among themselves and to intimidate smaller frms. The effect of large organizations on the legislative process occurs because:

Large companies start with certain inital political disadvantages because they are in the spotlight, because there is some suspicion of their power, and because small companies are more numerous. However, the large company can often overcome its handicap and obtain a decided advantage by political expenditures. The campaign contributions of large companies and the occastonal case of direct or indirect bribery are probably the least significant sources of the large company's political power. More imporfant, the large company spends whatever money is needed to argue effectively on behalf of its interest where a political issue affects it. . . While some smaller business interests make a comparable showing through associations set up for the purpose, the experience of a Washington official is that small companies generally find out what is happening too

George J. Stigler, The Theory of Price (New York: The Machillan Company, 1966), p. 85.

TThese are the effects briefly mentioned by Samuel H. Talley, "The Impace of Holding Company Acquisitions on Aggregate Concentration in Banking," Staff Economic Studies, no. 80 , Board of Governors of the federal Reserve System, pp. 1-2. The problem is analytically the same as that discussed by Corwin D. Edwards, "Conglomerate Bigness as a Source of Power," Business Concentration and Price Policy (Princeton: Princeton University Press, 1955), pp. 331-52, and in an accompanying "Comment" by George W. Stocking, pp. 352-59. late and prepare their cases too scantly and hastily to be fully effective where their interests conflict with those of large companies. ${ }^{8}$

Numal Fonoamon - The hypothesis that bank holding companies operating in several markets can agree on, and therefore affect, prices in those markets can be illustrated with a simple example. Suppose there are ten banking markets in a state and two banks in each market. Initially these banks are independently owned, but subsequently each of two holding companies in the state acquires one bank in each market. The hypothesis - sometimes called "mutual forbearance" - is that the two holding companies would be more likely to reach an agreement to raise prices in the ten markets than would the two banks in each market separately. ${ }^{9}$ Thus, the prices paid for services by bank customers would be expected to rise on average.

But are there really forces leading to mutual forbearance? Would the two holding companies in this example be more likely to agree than the twenty individual banks?

The arguments supporting this hypothesis are that the benefits from such an agreement would be greater, and the costs of deviating from it - chiseling - would also be greater than if all the banks were individually owned. One agreement, instead of ten, could apply to all markets; therefore, the benefits would be greater from an agreement. If one of two banks in a market cheated on the agreement, that is, lowered prices for at least some customers, then the decrease in prices would occur in only one market. But if one of the two holding companies cheated in a market, then the "price war" could spread to all markets. Thus, the costs of deviating from an agreement would also be greater.

The mutual forbearance hypothesis is not, however, substantiated by any empirical tests for banking or other sectors of the U.S. economy. Furthemore, the arguments for it are less than completely convincing. The inherent desirability of one agreement is dubious. The primary defect of one overall agreement is the existence of different demand and cost conditions in different markets; under these conditions, ten separate

BEdwards, "Conglomerate Bigness," pp. 346-47.

An increase in state concentration of deposits does not, how ever, necessarily reflect an increase in the probability of mutual forbearance. Such an increase may result from deposit growth in only one bank or acquisitions in markets where no other state-wide banking organizations operate. In these cases, banking organizations would not be facing each other in more markets than before. 
agreements could be superior from the holding companies' point of view. Also, it has in no way been established that an appropriate response to chiseling in one market would be a price war in all ten markets. This would only ensure that the decreased "profits" in one market would spread to ten markets.

Predatory preng - The ability of large organizations operating in several markets to discipline smaller ones operating in one market is the other alleged way that large organizations could increase prices paid by customers. In other words, if a small firm should be so bold as to chisel, it is argued that the larger organization would respond by cutting its prices in order to decrease the "profits" of the small chiseler." This practice has often been called "predatory pricing" or "cutthroat competition." It may be designed either "to teach the chiseler a lesson," to drive him into a merger, or to force him out of business. The large firm would have no differential advantages when it cuts prices unless it incurs costs greater than its revenue. Both the larger and the smaller firms would simply make less "profit" than they would otherwise. The large firm could only have a differential advantage when it is incurring losses.

The advantage attributed to large firms when they cut prices below their cost and their competitors' costs is superior access to capital - a lower price paid for capital. They could finance the losses at a lower cost than smaller firms; therefore, they would have a differential advantage in a price war. This lower cost of capital to large firms purportedly exists because the price war could be financed by funds generated in other markets where the larger firms are receiving "monopoly profits." But the large firm would not really have a lower cost of capital. The cost of anything is the highest-valued alternative foregone. And as long as one of its alternatives would be to loan to a small firm (with a cost of capital the same as the small firm it is trying to intimidate), then this alternative would be superior to financing a price war.

An additional argument against the likelihood of predatory pricing is summarized by George $\mathrm{J}$. Stigler in a fictional discussion in which a potential victim of predatory pricing by John D. Rockefeller tells a lender:

\footnotetext{
${ }^{10}$ This decrease need not involve a price cut below marginal cost, as has been argued by B. S. Yamey, "Predatory Price Cutting: Notes and Comments," Journal of Law and Economics (April 1972), pp. 129-42. He also provides a summary and evaluation of the literature generated by the elassic paper on this subject, John S. McCee, "Predatory Price Cutting: The Standard Oil (N. I.) Case," Joumal of Law and Economics (October 1958), pp. 137-69.
}

"There is a threat of a three-month price war, during which I will lose $\$ 10,000$, which unfortunately I do not possess. If you lend me the $\$ 10,000,1$ can survive the price war - and once I show your certified check to Rockefeller the price war will probably never be embarked upon. Even if the price war should occur, we will earn more by co-operation after ward than the $\$ 10,000$ loss, or Rockefeller would never embark upon the strategy,"11

And indeed, Rockefeller did buy out his rivals rather than try to drive them out of business by such tactics.

It is noteworthy that one cannot conceive that bank regulators would allow a price war. As a matter of fact, much of bank regulation is designed to suppress price competition, replacing it with other forms of competition. As Ray M. Gidney, a recent Comptroller of the Currency, said:

I think the important thing we should hope for is a degree of enlightenment on the part of people that run these banks so that they go out and give service. That is where we want competition, competition in giving service. ${ }^{12}$

Concentration of Political Power-For large firms to have a disproportionate effect on legislation, it would be necessary for them to have a differential advantage in contributing to political campaigns, delivering votes, or providing information to legislators. These are the three means by which politicians' votes in legislatures can be influenced..$^{13}$

At least in banking, there is no presumption whatsoever that large organizations have any differential superiority in any of these activities. Campaign contributions by corporations are illegal, and therefore will not generally be made. The wealth position of small banks' stockholders generally would be more substantially affected by banking legislation than the wealth position of stockholders of large banking organizations. Therefore, the small number of stockholders of numerous small banks are more likely to make contributions and vote on the basis of legislators' votes on banking legislation than are the numerous stockholders of a few holding companies. It is also unlikely that large holding companies have any superiority over small banks in supplying information to

${ }^{11}$ George J. Stigler, The Organization of Industry (Homewood: Richard D. Irwin, Inc, 1968), p. 116.

12U. S. Congress, Senate, Regulation of Bank Mergers, $86 \mathrm{th}$ Cong. Ist sess., 1959, Commtttee on Barking and Currency, p. 31. For an economic analysis of why producers prefer to substitute nomprice competition for price competition, see Stigler, The Organization of Industry, pp. $23-28$.

13 See Abert Breton, The Economic Theory of Representative Government (Chicago; Aldine Publishing Co., 1974), pp. $74 \times 98$. 
legislators. Bankers, through state and independent bankers associations, are well organized, whether they are large or small.

Thus, just as increased state concentration does not necessarily have any effects through mutual forbearance or predatory pricing, there is no substantial effect of increased state concentration on the legislative process.

\section{Market Concentration}

There are two hypotheses related to increased market concentration. One hypothesis is that increased concentration is associated with lower prices charged to customers due to the efficiency of large-scale operations. According to the second hypothesis, increased concentration facilitates agreement - explicit or tacit collusion - about prices in the market and is thus associated with higher prices charged to customers. 1.t Those who are in favor of relatively few re strictions on branching and acquisitions by multiple bank holding companies assert the first hypothesis when presenting their views. Those who are opposed to branching and holding company acquisitions of banks refer to the second hypothesis when interpreting the higher concentration which results from branching and multiple bank holding companies.

Efficiency - The hypothesis relating efficiency and concentration is an attempt to answer an important question: How does higher concentration develop? Higher concentration is synonomous with higher market shares of the larger firms. The arguments advanced in the discussion of state concentration imply that high market concentration does not result from predatory pricing by larger firms.

A firm's larger share of a market means that a larger percentage of the business in the market is going to that firm. This larger share of the business must result because customers prefer that firm to others, perhaps because of a lower price or a higher-quality product. Thus, it can be argued that concentration is higher because some firms are relatively more efficient.

This argument is weaker for banking than for other industries because of entry and branching regulations. Implicit in the argument is the assumption that the most efficient firms in servicing customers are those

14The tuse of the term "collusion" in this paper is not to be confused with the legal definition. Collusion as used in this paper includes legal collusion and a great deal more - any explicit or implicit agreement - not just explicit agreements. Those setting the prices need not even intend to agree; they need only act as if they agree. that are presently operating and that expansion is largely determined by relative efficiency. But entry regulation is designed precisely to protect existing banks from the competition of new banks; this is also a consideration in branching applications. Also, banking regulators determine to some extent who receives charters and which banks grow through branching. The interests of regulators and bank customers are not necessarily coincident.

Existing empirical evidence does not falsify the hypothesis that increased concentration results from the relative efficiency of larger banks. ${ }^{18}$

Collusion - The increased concentration, according to the second hypothesis, facilitates collusion among banks. Just as a single firm operating in a market maximizes the wealth of all the owners of the firm, an agreement between firms operating in a market can maximize the wealth of all the owners of the firms. There is, of course, a problem of distributing the gains from the agreement, a problem which does not arise for a monopoly.

Each of the firms in a market can increase the wealth of its owners if it cheats on the agreement while all other firms adhere to it. The chiseling can take various forms. It may be secret price cutting, changes in credit terms, or changes in the quality of the product in some other way. Whether the firm is cutting its pecuniary prices or making the nonpecuniary terms of its sales more attractive to buyers, it will desire to keep its actions secret. If the other firms

${ }^{15}$ Much of the literature on the relationship between bank's sizes and efficiency - so"called "economies of scale" - is reviewed and analyzed in Jack M. Guttentag and Edward S. Herman, "Banking Structure and Performance" The Bulletin of New York University Graduate School of Business Administration (February 1967), pp. 105-25, 169-96. Two recent studies are: Frederick $W$, Bell and Neil B. Murphy, "Costs in Commercial Banking," Federal Reserve Bank of Boston Research Report No. 41; and Lionel Kalish III and R. Alton Gilbert, "An Analysis of Efficiency of Scale and Organizational Form in Commercial Banking," Journal of Industrial Economics (July 1973), pp. 293-307. The empirical evidence generally indicates that banks of less than about 810 million deposit size are relatively high-cost banks and that other banks probably have about the same average cost.

There are, however, unresolved conceptual and neasurement problems, which apply to all studies of economies of scale in banking, that imply the empirical evidence must be interpreted carefully. Two of these problens are the inability to accomnt adecuately for changes in the types of deposits received and loans made as sizes of banks expand and the individual natire of banks' cost functions. For elaboration and analysis of the latter problem, see Milton Friedman's "Comment," pp. 230-38, on Caleb A. Smith "Survey of the Empirical Evidence on Economies of Scale," pp. 213 30 , in Business Concentration and Price Policy, and Harold Demsetz. "Industry Structure. Market Rivalry, and Public Policy," Journal of Law and Economics (April 1973), pp. 1-9. Interpreted in the light of Friedman's and Demsetz's analyses, the empirical evidence is consistent with larger banks being larger becalse they are more efficient. 
find out, they will take account of the price cutter's actions and set a lower price or improve the nonpecuniary terms of their sales.

This antagonism between the interests of the firms with an agreement is the basis of the relationship between market concentration and the prices charged customers in markets. The smaller the number of firms in an agreement and the larger their relative market shares, the easier effective collusion is likely to be. ${ }^{16}$

Another enemy of collusion, second to existing firms' mutual antagonism, is entry of new firms into the market. Those not presently in the market are not part of the agreement and, seeing the returns being received by firms in the market, are likely to be induced to enter. If they are subsequently made part of the agreement, the returns to those originally colluding are diluted. If they are not made part of the agreement, then the effect on the collusive prices is the same as that of a discovered chiseler - a lower price.

Entry and the possibility of it can attenuate the relationship between concentration and prices. But regulation of entry in banking effectively protects many markets from entry and in all cases reduces the probability of entry.

If increased collusion follows from increased concentration, one would expect to observe higher loan rates and higher rates of return for banks. The existing empirical evidence does not falsify this hypothesis either. ${ }^{17}$

\footnotetext{
11 Thomas R. Saving, "Concentration Ratios and the Degree of Monopoly," Intemational Economic Review (February 1970), pp. 139-46, brielly presents the theory behind the concentration ratio as a concentration measure. George $I$. Stigler "A "Theory of Oligopoly," Jourtal of Political Econ" omy (February 1964), pp. 44-61, analyzes the matual antagonism and relates enforcenent oosts to the Herfindahl index of concentration. Concentration ratios and Heffindahl indexes are highly correlated.

17Guttentag and Hemar, "Banking Structure and Performance, pp. 80-104, also review the evidence accumulated before 1967 on the relationship between concentration, prices, and "profits." Additional evidence is provided by Donald P. Jacobs, Business Loan Costs and Bank Market Structure: An Empirical Estimate of Their Retations, Occasional Paper 15, National Burean of Economic Research, and Amold Heggestad, "Market Structure, Risk, and Profitability in the Banking Industry" in Proceedings of a conference on Bank Structure and Competition, Federal Reserve Bank of Chicago, 1972. Taken as a whole, the empirical evidence is consistent with a statement that higher concentra-
}

\section{CONCLUSTON}

The controversies over branching and multiple bank holding company expansion are concerned with the effect of these multi-office organizations on concentration. In larger SMSAs, the Eighth District states with limited branch banking tend to have higher concentration of deposits in the four largest banking organizations than the unit banking states. State concentration has increased as a result of the rapid expansion of multiple bank holding companies in Missouri and Tennessee, but the effect on SMSA concentration has been somewhat less.

These findings are of little interest until the implications of increased concentration are assessed. It has been shown that there are no convincing arguments and no empirical evidence that state concentration has any significance. On the other hand, evidence has been advanced which supports both the hypothesis that increased market concentration results from the efficiency of large organizations and the hypothesis that increased concentration facilitates collusion among the organizations. The relationship between efficiency and concentration, by itself, implies that banks' customers gain as a result of higher concentration; but the relationship between collusion and concentration, by itself, implies that banks' customers lose as a result of higher concentration. Less restrictions on branching and multiple bank holding companies is associated with higher concentration. Therefore, there are both potential benefits and costs for banks' customers from such lessened restrictions.

Since it is so often thought to be implied, it is necessary to point out that this amalgam of collusion and efficiency does not imply that omniscient regulators could weigh the costs and benefits of higher concentration and determine a more "optimal" banking structure than that which would develop by permitting free market forces to operate. Such a weighing process is impossible. The evidence regarding both costs and benefits is imprecise and hobbled by the use of available accounting data to measure economic concepts. It is unlikely that the factors that result in imprecision will soon be overcome and even more unlikely that present accounting data can be replaced by more relevant data.

tion results in higher rates on loans and higher rates of return for banks. 


\section{APPENDIX: SELECTED BANK REGULATIONS IN EIGHTH DISTRICT STATES}

Regulation of banking can directly affect banking structure through limitations on entry, mergers, branching, and acquisitions of banks by multiple bank holding companies. All of these activities are subject to regulation at both the Federal and state levels. ${ }^{1}$

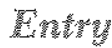

Before a bank may begin operations, Federal or state banking officials must grant a charter to the bank's organizers. The division of authority for examining charter applications, as well as applications for other actions discussed in this Appendix, is shown in Table A-I.

One purpose of entry regulation is to prevent a new bank from opening where it might fail or its opening might cause an existing bank to fail. Therefore, the Fed- eral banking officials consider the future earnings prospects of the bank and the effect of entry on the "soundness" and earnings prospects of existing banks. They also consider the effect of the new bark on the "convenience and needs of the community to be served" - that is, the extent to which the new bank might provide more services or services at lower cost than are currently available. The state laws, which are similar to the Federal laws, are outlined in Table A-II.

The concern of bank chartering agencies that existing banks not be hurt by new entry and that new banks meet a "needs" criterion has resulted in fewer banks being chartered than would have been in the absence of such regulation. ${ }^{2}$ One effect of this relative difficulty of entry has been to limit the development of competition in banking.

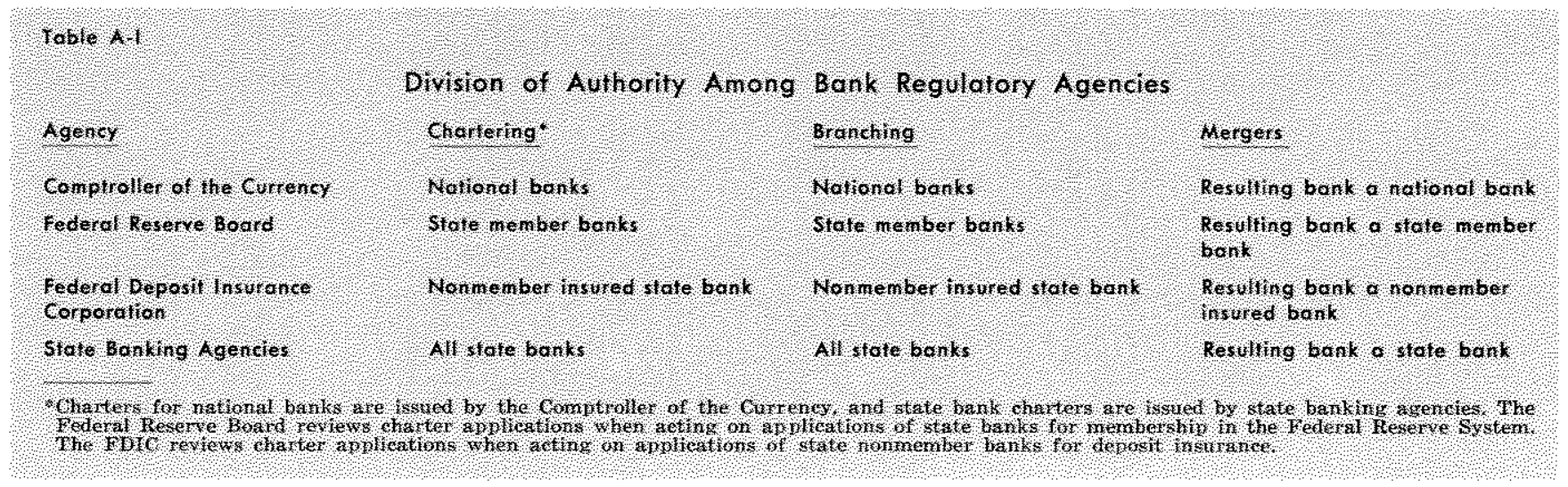

For a more detailed discussion of Federal regulation, see Gerald C. Fischer, American Banking Structure (New York: Columbia University Press, 1968). Tables at the end of this Appendix provide some of the details of state laws on entry, mergers, branching, and multiple bank holding companies.
${ }^{2}$ For a discussion of entry into banking, see Sam Peltzman, "Entry in Commercial Banking," Journal of Law and Economies (October 1965), pp. 11-50. 
1. Persons Applying

Arkonsos 5 or more qualified thatural persons, majority Arkansas residents, with confidence of community.

Illinois

5 or more incorporators, resi dents of Itinois, with general character suct that "reasonable promise of successtul operation exists."

Indiano

10 or more natural persons of lawful age, majority Indiana residents.

Kentucky 5 or more persons for bank; 7 or more for trust; 7 or more for bank \& trust; 13 or more for bank, frust, and real estate title.

Mississippi

5 or more persons of full age and of good moral and business character.

Missouri

5 or more persons with charac. ter, responsibility, and general fitness of person such as to command confidence.

Fernessee

5 or more incorporalors, majority residents of Tennessee; proposed officers and directors have sufficient experience. ability, and standing to assure reasonable promise of successful operation.
2. Capital Requirements Requisite capital subscribed in good faith, the ninimum depending on community size.

Meets minimum capital require ments, the minimum depending on community size.

Meets minimum capital require. ments, the minimum depending on community size.

Meets minimum capital requirements, the minimum depending on city size.

Copizal stock and surplus required, the minimum depending on communify size.

Requisite capital subseribed in good faith and paid in cash, the minimum depending on commurity size.

Adequate capital and surplus the minimum depending on community size.
3. Bonk's Prospects

Future earnings favorable.

Approval of Deparlment of Fincencial Institutions "in its distretion".

Recsonable assurance of sufficient volume of business for success.

Reasonable prospects of growth of the area and its financiol resourtes, expectations of profitable operations.

Probable volume of business in locality sufficient to insure and maintain solvency of the new bank.

Conditions in community affard teosonoble promise of successful operation.

\section{Convenience \& Needs There exists a public necessity of the business of the com- munity.}

Convenience and needs of area sought to be served will be promoted.

Approval by Department of Financial Instifutions "in its discretion".

Public convenience and adyantage will be promoled.

Defermine whether the public necessity requires that the proposed new bank should be chartered and allowed to operate.

Convenience and need of community justify and warrant opening of new bank.

Public need and advantages promoted.
5. Adverse Effect on Other Banks

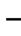

(2)

Approval by Department of Financial Insthutions "in it: discretion ".

lecord of earnings and con dition of existing unit banks (not branch banks) and effect on them.

Probable volume of business in lacality sufficient to main tain solvency of new bank and existing banks, withoul endangering safely of any bonk.

Need in community for now bark, considering adequacy of existing banks. 


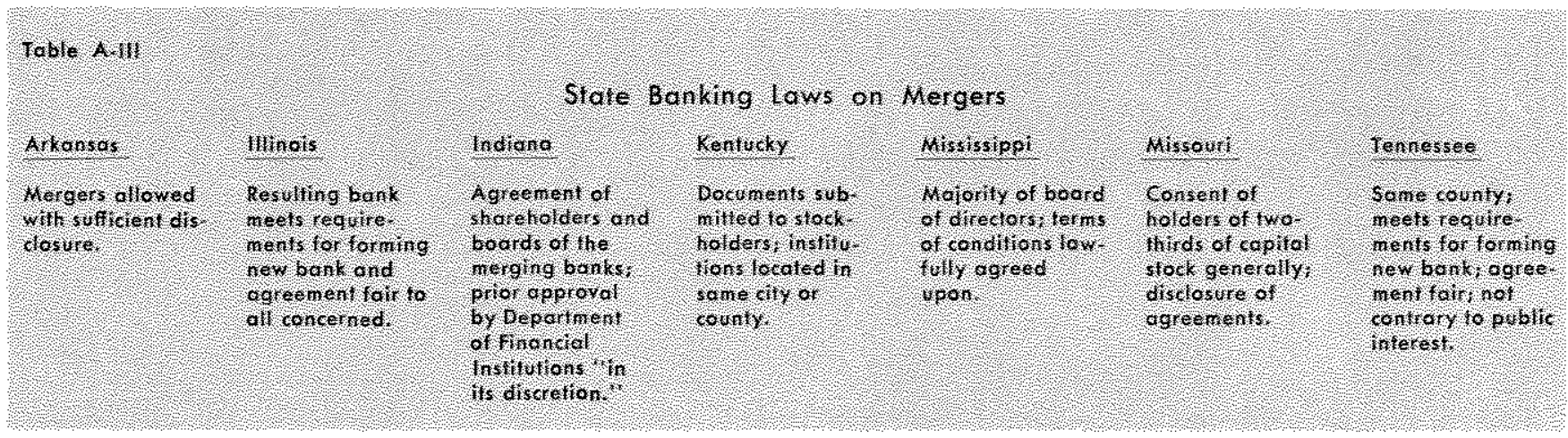

\section{Mergers}

Prior approval by a Federal banking agency is required for all mergers resulting in an insured bank. If the resulting bank is to be a state bank, approval of state banking officials is also necessary. The provisions of state laws on mergers in Eighth District states are outlined in Table A.III.

In deciding whether to approve or deny a merger application, Federal banking officials are required by the Bank Merger Act to consider the effects of the merger on competition, the future prospects of existing and proposed institutions, and the convenience and needs of the community to be served. No merger which would result in a monopoly or would tend to create a monopoly can be approved. If a merger would result in a "substantial lessening of competition," it can be approved only if the probable effects of the merger in meeting the convenience and needs of the community to be served clearly outweigh the anticompetitive effect.

\section{Branching}

All banks in a state, whether national or state-chartered, are subject to state laws concerning the locations of branches, the number of branches allowed, the services that may be offered, and the capital required for opening a branch.

There are both unit banking and limited branch banking states in the Eighth District. The least restrictive state law (Mississippi) permits branch banking withix 100 miles of a bank's home office. The provisions of the present state laws are contained in Table A-IV, p. 22

\footnotetext{
3This term is not defined in legislation but refers to a less extreme reduction in competition than would result from creation of a monopoly.
}

\section{Multiple Bank Holding Companies}

Federa - - Prior to 1956 , the bank acquisitions of multiple bank holding companies were virtually free of Federal regulation. The Bank Holding Company Act of 1956 brought this activity under Federal control by requiring prior approval by the Federal Reserve Board of any action resulting in ownership of 5 percent or more of a bank's stock by a company owning two or more banks. In determining whether or not to approve an acquisition, the Board was required to consider banking and competitive factors, but the competitive factors were given less emphasis than the so-called banking factors. In addition, acquisition of a bank outside a holding company's home state was prohibited, unless the acquired bank's state law specifically allowed such acquisitions.

Amendments to the Bank Holding Company Act which were passed in 1966 and 1970 shifted the emphasis from banking factors to competitive factors and brought onebank holding companies under the Board's supervision. The 1966 amendments provided that the Board apply the same tests in considering acquisitions by bank holding companies that Federal offcials apply in bank merger cases. The 1970 Amendments brought companies owning one bank under the purview of the Board.

Stare-- Formation of multiple bank holding companies is prohibited in the majority of the Eighth District states. This has been the case for some time in Illinois, Indiana, Kentucky, and Mississippi.

In 1971, an Arkansas law was passed which prohibits companies from becoming multiple bank holding companies or existing holding companies from making any further acquisitions; prior to that time, there had been no restrictions on such companes in Arkansas. Until this year Missouri and Tennessee had no restrictions on multiple bank holding companies; both states now have laws which limit the size of holding companies. The Tennessee Bank Structure Act of 1974 places additional restrictions on holding company acquisitions. Details of state laws are provided in Table A-V, p. 23. 
Table A.IV

\begin{tabular}{|c|c|c|c|}
\hline & Which Banks & Number of Defoched Offices & Location \\
\hline Arkansos & Any bank. & $\begin{array}{l}\text { No limit on number of full. } \\
\text { service branches. }\end{array}$ & $\begin{array}{l}\text { Within corporate limits of } \\
\text { home-office city or lown if } \\
\text { greater than } 300 \text { feet from } \\
\text { any other bank; in any city } \\
\text { or town in home-office } \\
\text { county with population af } \\
\text { least } 250 \text { and no home office } \\
\text { of another existing bank; in } \\
\text { any planned community de- } \\
\text { velopment in home-office } \\
\text { counfy with population at } \\
\text { least } 250 ; \text { nothing ollows } \\
\text { branches outside home- } \\
\text { office county. }\end{array}$ \\
\hline Illinois & Any bonk. & One Facility, & $\begin{array}{l}\text { Not more than } 1500 \text { feet } \\
\text { from home office and gea- } \\
\text { erally more than } 600 \text { feet } \\
\text { from other banks' premises. }\end{array}$ \\
\hline
\end{tabular}

Iadiona (a) Afy boak. population less than 500,000 or hoving 3 ot more second-class cities. population greater than 500,000 and less than 3 second-ciass cities.

Kenfucky (a) Any bank with sapita and surplus not less than $\$ 100,000$ with principol of fice in an area with populotion less than 8,000 .

Mississippi (b) Banks in counties with (c) Banks in counties with

(b) Any bank with capital and surplus not less than $\$ 200,000$ with principal of fice in a city with population of 8,000 or more and less than 20,000.

(c) Any bank in tity with population of 20,000 or more.

(a) Any bank. (a) One branch for every $\$ 200,000$ of capital and surplus.

(b) No limit.

(c) No limit.

(a) One bronch for each $\$ 100,000$ of capifal and surplus.

(b) One branch for each $\$ 200,000$ of copital and surplus.

(c) One branch for each surplus.

(a) Branch offices - no limit. $\$ 250,000$ of capital and

(a) Anywhere in county.

(b) Any city or fown in home-office county if no bank located in the city or lown.

(c) Any city or town in county.

(a) County-wide branching except if home office of another bank in lown of cily (but not branching bank's home-office (own) or it home office of another bank in unincorporoled area within one mile.

(b) Same as (a)

(c) Some os (a)

(a) Within home-office city if population af least 10,000 and within home office county and adjucent counties, but not in any city or town with population less thon 3500 and one or more exist. ing banks or branch bonks.

(b) Someas (o).

(b) Banks in third-class counties with population of 35,000 or less. (b) Branch banks maxi ma mum of 15 ; caplial require ments of $\$ 100,000$ plus minimum capital required for unit bonk at location.

(a) Two facilities. (a) Any bonk. mith or fown with population less than 3100 and one or mote existing bonks.

(a) Within limits of cify, town, or village or unincorporated area in which home office is localed and homeoffice county (but not within 400 feet of another bonk generalyl.

(b) In a fown with popula. tion of 1550 or less, which does not have banking sery

Missouri

Powers

All lawful barking activisies as fully as in the main office.

Receive deposits, costh and is sue thecks, drafts and money orders, change money and receive poyments on existing debis.

(a) (Powers of bank.)

(b) Same as (a)

(c) Sameas (o).

(a) Some powers os prin. cipal ofice.

(b) Some as (a)

(a) (Powers of bank.) ices and is not more then 10 miles from the bank's main office.

Within home-office county.

(a) Checks paid, deposits received, deposits withdrawn, change mode, exchange made, bank money orders issued, safe deposit boxes maintained and rented and loan payments received. (b) Same as $(a)^{1}$.

(Powers of bank.)

Tennesseme

Any benk.

No statutory limit on the number of branches.

1oans may naw be made al these facilities, pursuant to Missouri Commissioner of Finance Ruling No. 15 of 1 une 27 , 1974. 
Table A-V

State Banking Laws on Multiple Bank Holding Companies (MBHCs)

\begin{tabular}{|c|c|c|c|}
\hline & ARKANSAS & ILLINOIS & INDIANA \\
\hline 1. Definition & $\begin{array}{l}\text { Company owning or } \\
\text { controlling } 25 \% \text { or } \\
\text { more of shares of } \\
\text { more than one bank. }\end{array}$ & $\begin{array}{l}\text { Company awning ar } \\
\text { controlling } 15 \% \text { or } \\
\text { more of shares of } \\
\text { more than one bank, } \\
\text { controlling election of } \\
\text { majorify of directors } \\
\text { of more than ane } \\
\text { bank, holding } 15 \% \\
\text { or more of voting } \\
\text { shares of more than } \\
\text { one bank in trust for } \\
\text { shareholdes' beneft. }\end{array}$ & $\begin{array}{l}\text { Company with } 25 \% \\
\text { ownership. }\end{array}$ \\
\hline
\end{tabular}

KENTUCKY

一

\author{
MISSISSIPPI \\ Any corporation with \\ any object, purpose \\ or power of directly \\ or indirectly organiz- \\ ing, owning, or op \\ erating barks in \\ groups or chains.
}

MISSOURI

-

2. Restrictions on

\begin{abstract}
(a) Becoming an
\end{abstract}
MBHC

(b) Acquisitions

Unlawful for an
MBHC to acquire MBHC to acquire
sets of a benk.

Unlawful for any $M B H C$ to take actions resulting in owning or controlling greate than $5 \%$ of voting shares of any bank.
Unlawful

(a)

\section{Unlawful for MBHC} to acquire greater than $5 \%$ control of any bank; also unlowful for subsidiary to acquire assets of any bank.

\begin{abstract}
No person (individval or company) may owf or control more than one hall of the capital stock in t
or more banks.
\end{abstract}

No person controllin of the copital stock in one bank may atquire any stock in another bank. more than one-half

Implicilly unlawful.)

Unlawful

(2)

(c) De novo bonks Unlawful

(Implicilly
unlawful.)

(Implicitly

unlawfel.)

(Implicitly unlawftl.)

Unlawful

Only closely relafed activities.

(a) Other 